\title{
TESTING SOME PEDO-TRANSFER FUNCTIONS (PTFS) IN APULIA REGION
}

\author{
Floriano Buccigrossi, Angelo Caliandro, Pietro Rubino, Mario Alberto Mastro
}

\section{Introduction}

The knowledge of the soil moisture vs. soil water matric potential is used to study irrigation and drainage planing, to determine the soil water storage capacity (plant available water), to study the solute movement, plant growth [Stanhill 1957] and water stress.

Hydraulic soil characteristics can be determined directly through physical and chemical laboratory analyses or indirectly by physical-chemical characteristics of pedological horizons [Rawls 1991] that affect soil water retention, such as sand, silt, clay content (particle size distribution) organic matter or organic carbon and total $\mathrm{CaCO}_{3}$ content, soil bulk density, aggregate size distribution, free iron oxide: parameters easely to determine, quickly and at low cost [Jamison 1958; Prebble 1959; Salter 1965 a; Salter 1965 b; Petersen 1968 b; Torrent 1983; Williams 1983; McKeague 1987; Wösten 1988; Lin 1999; Rawls 2001; Rawls 2002 a; Rawls 2002 b; Pachepsky 2003; Rawls 2003]; recently also topografic variables have been introduced such as altitude and slope [Odeh 1994; Romano 2002; Leij 2004]. For this derivation PedoTransfer Functions (PTFs), expression used by Bouma (1989), can be utilized.

The use of PTFs to estimate some hydrologic soil characteristics is based on three fundamental principles [Ungaro 2001]:

- the PTF's parameters are directly correlated with particle size distribution and other physical-chemical soil characteristics and parameters [Nielsen 1958; Lund 1959];

- the water content values can be estimated at specific matric potentials, depending from available data;

Paper received 25.09.2007; accepted 13.01.2009

Buccigrossi F. Post-Doctor (flo.buccigrossi@libero.it), CALIANDRO A. full professor (caliandro@agr.uniba.it), RUBINO P. full professor (pietro.rubino@agr.uniba.it), MASTRO M.A. high technical skills (mastroalberto@agr.uniba.it) respectively; Dipartimento di Scienze delle Produzioni Vegetali, Università di Bari, via Amendola 165/A, 70125 Bari, Italy afterwards, entire water retention curves are derived;

- at specific matric potentials values, a physic-empirical relationship is always defined between particle and pore size distribution and soil water content.

PTFs field research is more and more dynamic such that has produced results generally satisfying even if the large majority of study have locality importance and empirical meaning [Petersen 1968 a; Maclean 1972; Ahuja 1985; Aina 1985; Meng 1987; Daamen 1990; Bell 1995; Tomasella 1998; Tomasella 2000; Hodnett 2002; Rajkai 2004].

Wide data sets have been utilized for PTFs development such us UNSODA [Nemes 2001; Nemes 2003], HYPRESS (European database with 1700 soil profiles and 5000 soil samples) [Wösten 1999], WISE (World Inventory of Soil Emission Potentials) [Batjes 1996], GOLD and the USDA Natural Resource Conservation Service pedon database, provided by homonymous society.

PTF models can be classified on the basis of nature and type of the input parameters:

- models utilizing physical-chemical parameters;

- models utilizing a physical-empirical approach estimating the water soil retention capacity throught pore size distribution [Brutsaert 1966; Farrel 1972; D'Hollander 1979] or particle size distribution and soil bulk density [Arya 1981; Haverkamp 1986; Tyler 1989].

Moreover, the first models can be differentiated in:

- linear regression models [Gupta 1979 b; De Jong 1983; Puckett 1985; Rawls 1986];

- non-linear regression and exponential models.

The last models are divided into three general groups and for their use the following perameters are estimated:

- the original parameters of van Genuchten equation [van Genuchten 1980] for determining the water soil retention curve [Rawls 1985; Wösten 1988; Vereecken 1989; Simota 1996; Scheiinost 1997];

- the parameters of Campbell equation (1974) [Ghosh 1980; Cosby 1984; Cresswell 2000];

- the parameters of Brooks \& Corey equation (1964) that, as the previous equations, relate the matric 
potential to the water soil content [Saxton 1986; Mayr 1999].

For the models that use physical-chemical parameters different levels of informations can be defined; each one individualizes one or more PTFs. According to the available data stored in the data base, it is possible to select the following PTF groups [Ungaro 2001]: Level 1: variables necessary are one or more particle size fractions (sand, silt and clay) [Stirk 1957; Nielsen 1958; Salter 1966; Aina 1985; Saxton 1986];

Level 2: variables necessary are one or more particle size fractions and organic matter content or soil bulk density [Salter 1969; Rawls 1982; Aina 1985; Rawls 1985];

Level 3: variables necessary are one or more particle size fractions, organic matter (or organic carbon) content and soil bulk density [Gupta 1979 b; De Jong 1983; Vereecken 1989; Simota 1996];

Level 4: variables necessary are one or more particle size fractions, organic matter (or organic carbon) content, soil bulk density and volumetric water content at -33 and $-1500 \mathrm{kPa}$ [Rawls 1982].

The objective of this study is to evaluate the applicability of six PTFs to estimate the volumetric water content at the field capacity and at the wilting point in soils of Apulia Region, utilizing soil samples deriving from pedons studied to build up the regional pedological map.

\section{Materials and methods}

\subsection{Soil samples set}

A data set of 361 soil samples collected from 185 pedological profiles (pedons) on Apulian territory have been used for this research (figure 1). For each pedon, one or more soil samples derive from one or more pedological soil layers, respectively. The soils, according to USDA texture classification, belong to the textural compositions listed in table 1.

Before making physical-chemical laboratory analyses, soil samples have been air-dried and $2 \mathrm{~mm}$ mesh sieved.

\subsection{Physical-chemical laboratory analyses}

On sieved samples, organic matter content (Walkley-Black method), particle size fraction [according with USDA texture classification (table 1 and figure $2)$ : coarse sand ( $2 \geq$ diameter $(\mathrm{d}) \geq 0.1 \mathrm{~mm})$, fine sand $(0.1 \geq \mathrm{d} \geq 0.05 \mathrm{~mm})$, coarse silt $(0.05 \geq \mathrm{d} \geq 0.02 \mathrm{~mm})$, fine silt $(0.02 \geq d \geq 0.002 \mathrm{~mm})$ and clay $(\mathrm{d} \leq 0.002$ $\mathrm{mm}$ ) (pipette method and determination of coarse sand with humid sieved)], water content (\% soil dried weight) at -33 [Field Capacity (FC)] and $-1500 \mathrm{kPa}$ [Wilting Point (WP)] with porous plates in Richards pressure chambers [Richards 1947; 1949] have been determinated.
Soil bulk density $\left(\rho_{\mathrm{b}}\right)$ can be directly determinated or estimated through specific models and/or PTFs [Curtis 1964; Saini 1966; Heinonen 1977; Gupta 1979 a; Alexander 1980; Rawls 1989; Leonavičiutè 2000]; in this case, having only soil samples $2 \mathrm{~mm}$ mesh sieved, the following equation [Adams 1973; Rawls 1982] has been applied:

where:

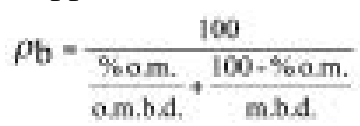

o.m.: organic matter;

o.m.b.d.: organic matter bulk density, on average equal to $0.224 \mathrm{~g} \cdot \mathrm{cm}^{-3}$;

m.b.d.: mineral bulk density, graphically obtained through a mineral density map based on sand and clay percentages (Davis 1973).

Considering the previous equation [Rawls 1982] to estimate the soil bulk density, the six PTFs have been applied only on the basis of organic matter and particle size distribution data set.

\subsection{Applied Pedo-transfer functions}

The PTFs studied and applied to estimate the volumetric water content $\left(\theta_{e s t}\right)$ at -33 and $-1500 \mathrm{kPa}$ matric potentials, are:

\section{GUPTA \& LARSON, 1979 (model I)}

Gupta \& Larson propose linear multiple regression functions utilizing particle size fractions [sand (Sa), silt $(\mathrm{Si})$ and clay $(\mathrm{Cl})$ ], organic matter content $(\mathrm{OM})$ and soil bulk density $\left(\rho_{b}\right)$.

The functions are:

1 - at the Field Capacity (- $33 \mathrm{kPa})$ :

$\theta_{\text {est }}=(0.003075 \cdot \mathrm{Sa})+(0.005886 \cdot \mathrm{Si})+$ $(0.008039 \cdot \mathrm{Cl})+(0.002208 \cdot \mathrm{OM})-\left(0.1434 \cdot \rho_{\mathrm{b}}\right)$;

2 - at the Wilting Point (- $1500 \mathrm{kPa})$ :

$\theta_{\text {est }}=(-0.000059 \cdot \mathrm{Sa})+(0.001142 \cdot \mathrm{Si})+$

$(0.005766 \cdot \mathrm{Cl})+(0.002228 \cdot \mathrm{OM})+\left(0.02671 \cdot \rho_{\mathrm{b}}\right)$

RAWLS et al., 1982 (model II)

Rawls et al., propose multiple regression functions to estimate water soil contents corresponding to ten values of matric potential $\left(\Psi_{\mathrm{Pm}}=-10,-20,-33,-60\right.$, $100,-200,-400,-700,-1000$ e $-1500 \mathrm{KPa})$. Water soil contents are calculated as follows:

1 - at the Field Capacity $(-33 \mathrm{kPa})$ :

$$
\begin{aligned}
& \theta_{\text {est }}=0.2576-0.002 \cdot(\mathrm{Sa})+0.0036 \cdot(\mathrm{Cl})+0.0299 \\
& \cdot(\mathrm{OM})
\end{aligned}
$$

2- at the Wilting Point (- $1500 \mathrm{kPa})$ :

$$
\theta_{\text {est }}=0.0226+0.005 \cdot(\mathrm{Cl})+0.0158 \cdot(\mathrm{OM})
$$

DE JONG et al., 1983 (model III)

To apply De Jong model, clay $(\mathrm{Cl})$ and silt $(\mathrm{Si})$ percentages, organic carbon content (OC) and soil bulk density $\left(\rho_{\mathrm{b}}\right)$ are necessary.

For $\Psi_{P m} \leq 10^{\mathrm{t}}$ where $\mathrm{t}=-1.12+0.029(\mathrm{Cl})$ the following function is being proposed:

$$
\theta_{e s t}=\left\{\mathrm{a}+\left[\mathrm{b}_{1}\left(\log \Psi_{P m}-\mathrm{t}\right)\right]\right\} \times \rho_{\mathrm{b}} / 100
$$


where $\mathrm{a}=6.4+2.78(\mathrm{OC})+0.24(\mathrm{Cl})$

$$
\mathrm{b}_{1}=-42.9+0.55(\mathrm{Cl})
$$

For $\Psi_{P m}>10^{t}$ the following function is being proposed:

$\theta_{\text {est }}=\left\{\mathrm{a}+\left[\mathrm{b}_{2}\left(\log \Psi_{P m}-\mathrm{t}\right)\right]\right\} \times \rho_{\mathrm{b}} / 100$

where $b_{2}=-1.56-[0.028(\mathrm{Si}+\mathrm{Cl})+0.24(\mathrm{OC})]$

$\Psi_{P m}$ in bar

RAWLS \& BRAKENSIEK, 1985 (model IV)

This PTF is based on the original Van Genuchten function (1980) and it allows to estimate different variables such as the air entry potential $\left(h_{b}\right)$; pore size distribution index $(\lambda)$; residual water content $\left(\theta_{\mathrm{r}}\right)$. These variables are used to estimate the van Genuchten function parameters ( $\mathrm{n}, \mathrm{m}$ and $\alpha$ that is equal to $\left.\left(h_{b}\right)^{-1}\right)$.

To determine these parameters, sand (Sa) and clay (Cl) percentages and the porosity $(\varnothing, \%$ in volume) are requested. Porosity is directly derived from soil bulk density $\left(\rho_{b}\right)$ and soil real density $\left(\rho_{d}\right)$, that, on average, is equal to $2.65 \mathrm{~g} \cdot \mathrm{cm}^{-3}$, throught the relation:

$$
\varnothing=1-\left(\rho_{b} / \rho_{d}\right) \quad \% \text { in volume }
$$

The saturation water content $\left(\theta_{\mathrm{s}}\right)$ is assumed to be equal to the porosity that is $\theta_{\mathrm{s}}=\varnothing$.

The Van Genuchten function is:

$\theta_{\text {est }}=\theta_{\mathrm{r}}+\left(\theta_{\mathrm{s}}-\theta_{\mathrm{r}}\right)\left[\left(1+\Psi_{P m} /\left.h_{b}\right|^{\mathrm{n}}\right)\right]^{-\mathrm{m}}$

where:

$\Psi_{P m}$ in dm

$\alpha=\left(h_{b}\right)^{-1}$;

$\mathrm{n}=\lambda+1$

$\mathrm{m}=\lambda(\lambda+1)$.

$h_{b}=\exp \left(5.34+0.185 \mathrm{Cl}-2.484 \varnothing-0.002 \mathrm{Cl}^{2}-\right.$ $0.044 \mathrm{Sa} \varnothing-0.617 \mathrm{Cl} \varnothing+0.001 \mathrm{Sa}^{2} \emptyset^{2}-0.009 \mathrm{Cl}^{2} \emptyset^{2}-$

$0.00001 \mathrm{Sa}^{2} \mathrm{Cl}+0.009 \mathrm{Cl}^{2} \varnothing-0.0007 \mathrm{Sa}^{2} \emptyset+$ $\left.0.000005 \mathrm{Cl}^{2} \mathrm{Sa}+0.5 \varnothing 2 \mathrm{Cl}\right)$

$\lambda=\exp \left(-0.784+0.018 \mathrm{~S}-1.062 \varnothing-0.00005 \mathrm{Sa}^{2}\right.$

$-0.003 \mathrm{Cl}^{2}+1.111 \emptyset^{2}-0.031 \mathrm{Sa} \emptyset+0.0003 \mathrm{Sa}^{2} \emptyset^{2}-$

$0.006 \mathrm{Cl}^{2} \emptyset^{2}-0.000002 \mathrm{Sa}^{2} \mathrm{Cl}+0.008 \mathrm{Cl}^{2} \varnothing-0.007$ $\left.\varnothing^{2} \mathrm{Cl}\right)$

$\theta_{\mathrm{r}}=-0.018+0.0009 \mathrm{Sa}+0.005 \mathrm{Cl}+0.029 \emptyset-$ $0.0002 \mathrm{Cl}^{2}-0.001 \mathrm{Sa} \emptyset-0.0002 \mathrm{Cl}^{2} \emptyset^{2}+0.003 \mathrm{Cl}^{2} \varnothing$ $-0.002 \varnothing^{2} \mathrm{Cl}$.

SAXTON et al., 1986 (model V)

Saxton' function derives from original Brooks \& Corey function (1964). Data concerning clay (Cl) and sand $(\mathrm{Sa})$ percentages, with diameter particle indicat-

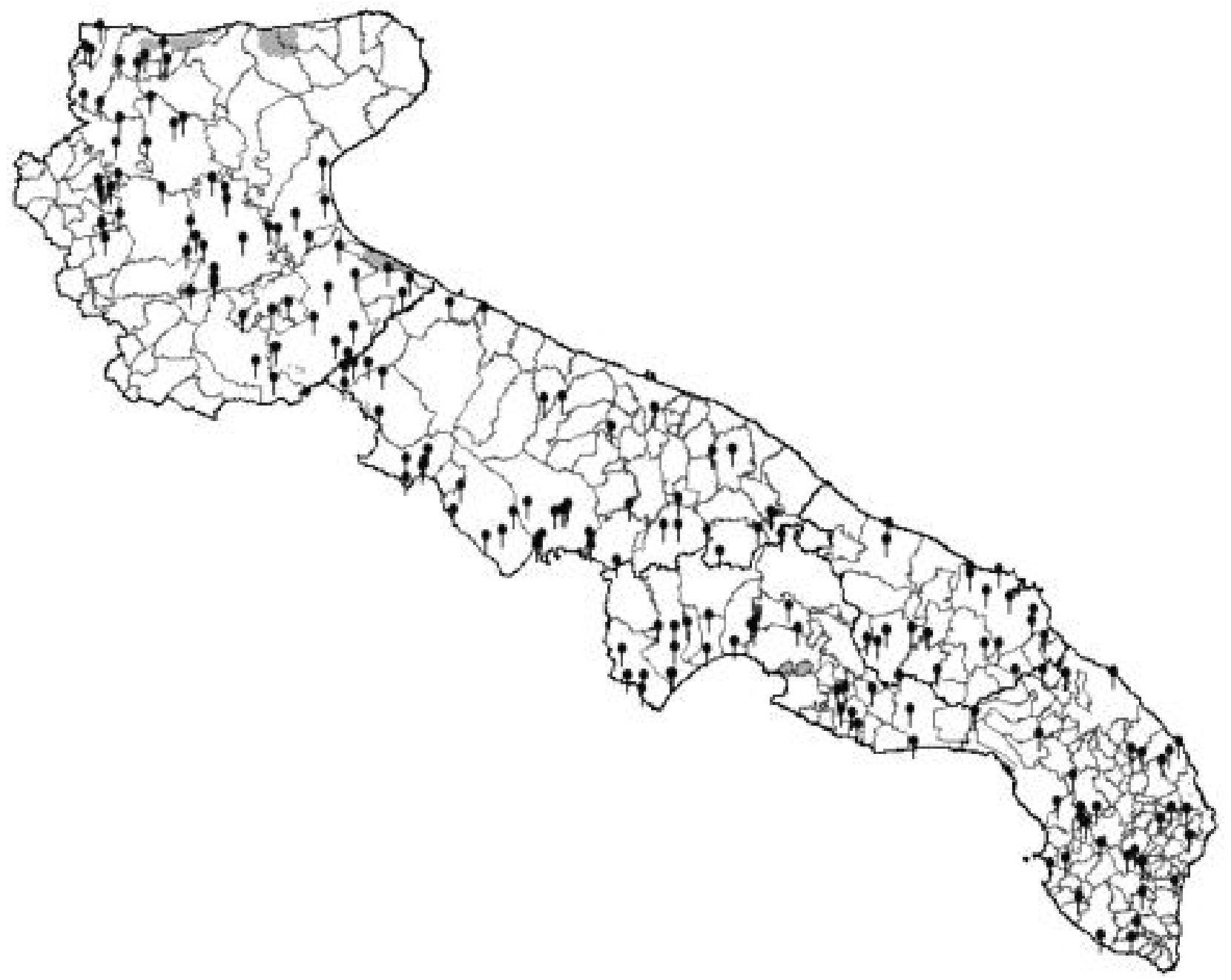

Fig. 1 - Localization of the 185 pedological profiles on Apulian territory. 


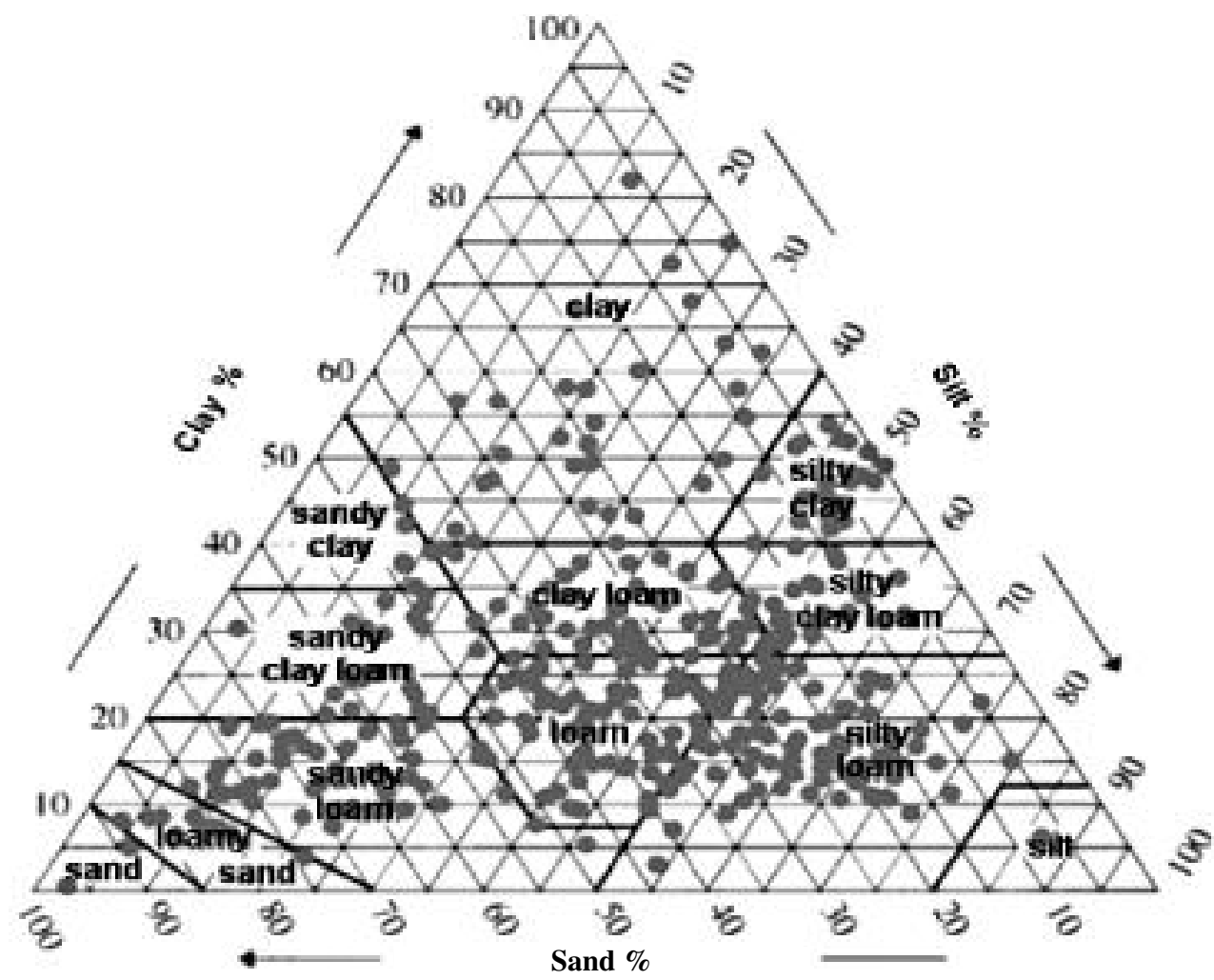

Fig. 2 - USDA soil classification of the examined soil samples.

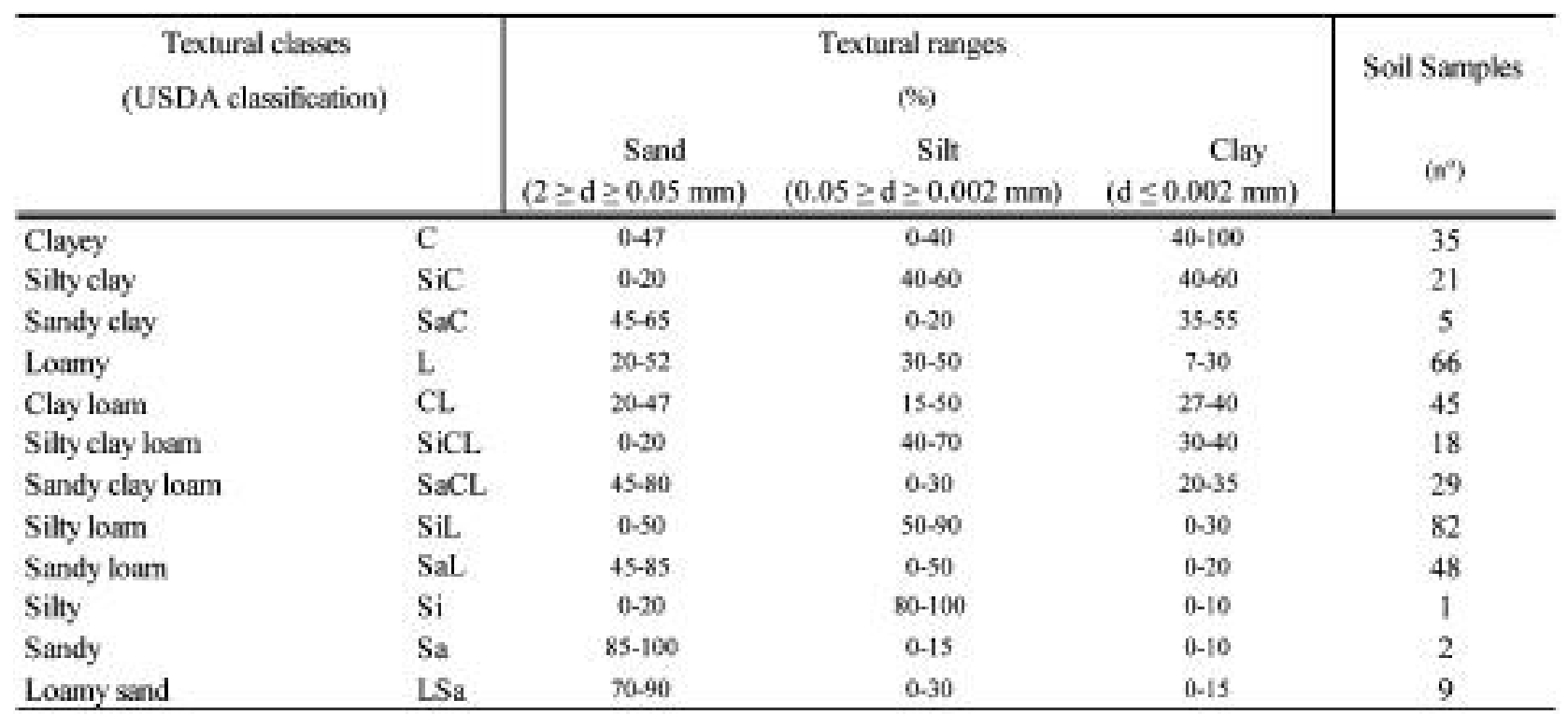

TABLE 1 - Textural classes (USDA textural classification) and relative number of soil samples for each class.

ed in USDA texture classification, are requested.

In three different matric potential ranges, three different functions can be individualize; particularly matric potentials $\left(\Psi_{\mathrm{Pm}}\right)$ between - $1500 \mathrm{KPa}$ and - 10 $\mathrm{KPa}$

where:

$$
\theta_{\text {est }}=\left(\Psi_{\mathrm{Pm}} / A\right)^{1 / B}
$$

$$
\begin{aligned}
& A=\exp \left[-4.396-0.0715(\mathrm{Cl})-4.880 \times 10^{-4}(\mathrm{Sa})^{2}-\right. \\
& \left.4.285 \times 10^{-5}(\mathrm{Sa})^{2}(\mathrm{Cl})\right] 100.0 \\
& B=-3.140-0.00222(\mathrm{Cl})^{2}-3.484 \times 10^{-5}(\mathrm{Sa})^{2}(\mathrm{Cl})
\end{aligned}
$$

VEREECKEN et al., 1989 (model VI)

As Rawls \& Brakensiek model (1985), Vereecken et al. model estimates the parameters of original Van Genuchten function (eq. 1) utilizing clay $(\mathrm{Cl})$ and sand (Sa) percentages, organic carbon content (OC) and soil bulk density.

$$
\theta_{e s t}=\theta_{\mathrm{r}}+\left(\theta_{\mathrm{s}}-\theta_{\mathrm{r}}\right)\left(1+\left|\alpha \Psi_{P m}\right|^{\mathrm{n}}\right)^{-1}
$$

The functions to estimate the parameters of Van Genuchten function are: 


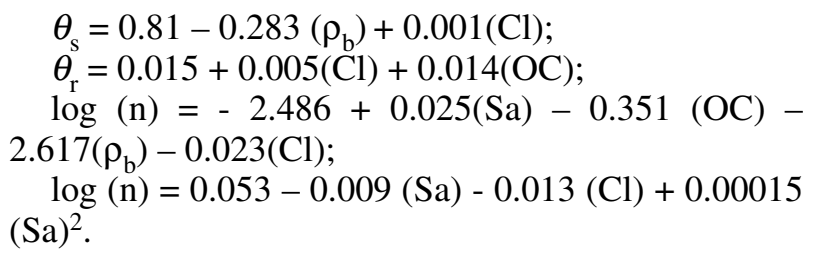

\subsection{Definition of Pedo-Transfer functions evaluation} criteria

For the differences between the values of water contents estimated with the six PTFs and those determinated in laboratory, relative to the total data set, statistic errors and correlations [Allen 1989; Wösten 2001] have been calculated, that is:

1- The Weighted standard error of estimate (WSEE), obtained through indexes, such as standard error of estimate (SEE) of the differences between measured and estimated soil moisture values with the six PTFs, and adjusted standard error of estimate (ASEE) of the differences between soil moisture values measured $\left(\theta_{m}\right)$ and estimated $\left(\theta_{\text {est }}\right)$ by regression lines through zero, giving a weight of 16 $\%$ to the soils tendentially clayey [(textural classes Clay (n. soil samples 35) and Silty Clay (n. soil samples 21)], of $3 \%$ to the soils tendentially sandy [(texitural classes Sand (n. soil samples 2) and Loamy Sandy (n. soil samples 9)], and of $81 \%$ to the other ones (n. soil samples 294); the applied relation is the following:

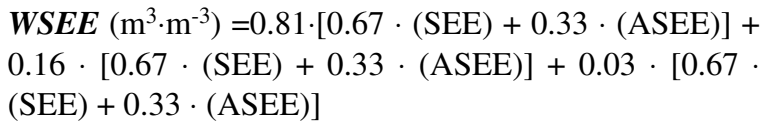

where 0.67 e 0.33 are the percentages of SEE and ASEE indexes on total error for each textural group, respectively [Allen 1989]; 0.03, 0.16 e 0.81 are the error percentages on WSEE index of the soils tendentially sandy and clayey and of the other tipes, respectively. The percentages are calculated as follow:

$$
\frac{\text { n. of soils in texitural group }}{\text { n. total of soils }}
$$

2- mean deviation (MD) or mean error (ME) between estimated $\left(\theta_{e s t}\right)$ and measured $\left(\theta_{m}\right)$ water retention values. $\mathrm{MD}$ is a positive or negative number according to whether the PTFs overestimate or underestimate the water contents, respectively;

3- root mean squared deviation (RMSD) or root mean square residual (RMSR) or root mean square error (RMSE);

4- determination coefficients $\left(R^{2}\right)$ between estimated and measured water retention values.

Analysis of variance and Student-Newman-Keuls tests have been applied on the statistic indexes MD and RMSD, utilizing SAS software (S.A.S. INSTITUTE INC.-USA) with 0,05 and 0,01 probability levels. The protected SNK test of Student-NewmanKeuls has been applied only to significant parameters.

\section{Results}

The results of the comparisons between estimated and measured water retention values utilizing the indexes previously indicated are reported.

\section{Weighted standard error of estimate (WSEE)}

WSEE index, calculated for clayey and sandy soils and for soils belonging to the remaining 8 textural classes, represented for $16-3$ and $81 \%$, respectively, has given different results for water content values at the Field Capacity (FC) and the Wilting Point (WP). In particular, at the FC (table 2), the lowest value (0.0607 $\mathrm{m}^{3} \cdot \mathrm{m}^{-3}$ ) has been obtained with model II demonstrating to be the best one. WSEE index values, which are the differences between soil moisture estimated and calculated, increased up to $0.0613-0.0651-0.067-0.100$ and to $0.104 \mathrm{~m}^{3} \cdot \mathrm{m}^{-3}$ with models VI, IV, I, V and III, respectively; the last model resulting the worst.

At the WP (table 3), the lowest value of WSEE index $\left(0.044 \mathrm{~m}^{3} \cdot \mathrm{m}^{-3}\right)$ has been observed with model IV. WSEE values rise to $0.048-0.053-0.054-0.060$ and to $0.069 \mathrm{~m}^{3} \cdot \mathrm{m}^{-3}$ with the application of models II, V, VI, III, I, respectively.

According to WSEE index, the models II and IV give the best performance at the $\mathrm{FC}$ and the WP, respectively.

\section{Mean deviation (MD)}

For the total data set, at the FC, the mean deviation values between soil moisture estimated with the six PTFs and measured in laboratory (table 4) show that 5 of them underestimate water content, while the model I overestimates the water content (on average 0.030 $\left.\mathrm{m}^{3} \cdot \mathrm{m}^{-3}\right)$. However, the lowest MD values $(-0.007$ and $\left.-0.019 \mathrm{~m}^{3} \cdot \mathrm{m}^{-3}\right)$ have been observed with the models II and VI, while the highest ones with the application of the models $\mathrm{V}$ and III $\left(-0.064 \mathrm{e}-0.081 \mathrm{~m}^{3} \cdot \mathrm{m}^{-3}\right)$.

At the WP, the models I, II and VI overestimate water contents $(5.3-0.6$ e $0.5 \%$ of volume, respectively), while the models IV, V and III underestimate water contents of $1.6-1.8$ e del $4.6 \%$, respectively.

MD index indicates that the models II and VI are the best to estimate the water content at the FC and the WP, respectively.

\section{Root mean squared deviation (RMSD)}

The RMSD values, calculated on the differences between the soil moisture estimated and measured at the FC and WP, are much the same of the WSEE values (table 4). At the FC, the RMSD values vary from $0.059 \mathrm{~m}^{3} \cdot \mathrm{m}^{-3}$, with model II, to $0.061-0.066-0.070$ $-0.102-0.121 \mathrm{~m}^{3} \cdot \mathrm{m}^{-3}$ with the models VI, I, IV, V and III, respectively, with significant differences between the first two for the lowest values, and between the last two for the highest values.

At the WP, the RMSD values vary from 0.046 and $0.047 \mathrm{~m}^{3} \cdot \mathrm{m}^{-3}$, with the models IV and II, to higher values such as $0.071 \mathrm{e} 0.072 \mathrm{~m}^{3} \cdot \mathrm{m}^{-3}$ using the models I and III. 


\begin{tabular}{|c|c|c|c|c|c|c|c|c|c|c|c|c|c|c|}
\hline \multirow{3}{*}{ PTF } & \multirow{2}{*}{$\begin{array}{c}\text { Straight } \\
\text { Ine slope } \pm \\
\text { stondsed } \\
\text { errors }\end{array}$} & \multirow{3}{*}{$\mathrm{R}^{2}$} & Significance & \multirow[b]{2}{*}{ SEE } & \multirow{3}{*}{ ASEE } & \multicolumn{4}{|c|}{ Tendency clayey sois } & \multicolumn{4}{|c|}{ Tendency sandy sois } & \multirow{2}{*}{$\begin{array}{l}\text { Weighted } \\
\text { standard error } \\
\text { (WSEE) }\end{array}$} \\
\hline & & & $\operatorname{Pr}>|t|$ & & & $\begin{array}{l}\text { Straight } \\
\text { line slope } \\
\text { I standard } \\
\text { errors }\end{array}$ & \multirow[t]{2}{*}{$\mathbf{R}^{1}$} & SEE & ASEE & $\begin{array}{c}\text { Sraght } \\
\text { ine slope } \\
\text { t standard } \\
\text { errocs }\end{array}$ & \multirow[t]{2}{*}{$\mathrm{R}^{2}$} & SEE & ASEE & \\
\hline & (b $(\mathrm{es})$ & & (b) & $m^{3} r$ & & $(b \pm e s)$ & & $\mathrm{m}^{3}$ & $m^{3}$ & $(b \pm e s)$ & & \multicolumn{3}{|c|}{$m^{3} m^{3}$} \\
\hline $\begin{array}{l}\text { Moset II } \\
\text { (Rasta) }\end{array}$ & $\begin{array}{c}0.955 \pm \\
0,009\end{array}$ & 0.97 & $<0,0001$ & 0,059 & 0,057 & $\begin{array}{l}0.96= \\
0.002\end{array}$ & 0.97 & 0,079 & 0,078 & $\begin{array}{l}1,48 \pm \\
0,086\end{array}$ & 0,97 & 0,064 & 0.024 & 0.0507 \\
\hline $\begin{array}{c}\text { Medel V } \\
\text { (Vereecken\}) }\end{array}$ & $\begin{array}{l}0.914 t \\
0,000\end{array}$ & 0.97 & $<0,0001$ & 0.061 & $0,063 \mid$ & $\begin{array}{l}0.89 x \\
0.02\end{array}$ & 0.97 & 0,087 & 0,060 & $\begin{array}{l}1.34 \pm \\
0,074\end{array}$ & 0,87 & 0,041 & 10,022 & 0.0813 \\
\hline $\begin{array}{l}\text { Model N } \\
\text { (Rawla \& } \\
\text { Enawenate) }\end{array}$ & $\begin{array}{l}0,85 \pm \\
0,007\end{array}$ & 0,97 & $<0,0001$ & 0.071 & 0.047 & $\begin{array}{l}0.88= \\
0.019\end{array}$ & 0.97 & 0,088 & 0,066 & $\begin{array}{c}1,40 \pm \\
0,1\end{array}$ & 0,96 & 0,060 & 0.031 & 0,0551 \\
\hline $\begin{array}{l}\text { Mosel I } \\
\text { (Guptas a } \\
\text { Larson) }\end{array}$ & $\begin{array}{l}1,06 \pm \\
0,0005\end{array}$ & 0.97 & $<0,0001$ & 0,068 & 0,082 & $\begin{array}{c}1,002= \\
0,0025\end{array}$ & 0.97 & 0,081 & 0.081 & $\begin{array}{c}1,67 \pm \\
0,1\end{array}$ & 0,85 & 0,072 & 0.031 & 0.087 \\
\hline $\begin{array}{l}\text { Model V } \\
\text { [Saxton] }\end{array}$ & $\begin{array}{l}0.82 \pm \\
0,01\end{array}$ & 0,92 & $<0,0001$ & 0,103 & 0,002 & $\begin{array}{l}1.05= \\
0.039\end{array}$ & 0.93 & 0,135 & 0,135 & $\begin{array}{l}0.92 \pm \\
0,06\end{array}$ & 0,96 & 0,018 & 0.016 & 0.100 \\
\hline $\begin{array}{l}\text { Modet III } \\
\text { 〈De Jang) }\end{array}$ & $\begin{array}{l}0,74 \pm \\
0,013\end{array}$ & 0.90 & $<0,0001$ & 0,122 & 0,084 & $\begin{array}{l}0.92 \pm \\
0.024\end{array}$ & $0, \infty$ & 0,093 & 0,084 & $\begin{array}{l}1,44 \pm \\
0,109\end{array}$ & 0,95 & 0,064 & 0.033 & 0.104 \\
\hline
\end{tabular}

TABLE 2 - Regression parameters between measured and estimated with six PTFs soil moisture values at Field Capacity (\% volume) setting intercepts to zero; indexes SEE, ASEE and WSEE values.

According to the RMSD index, as well the WSEE index, the models II and VI, at the FC, and the model IV and II at the WP, are satisfactory. The less accurate soil moisture estimates have been obtained with the application of the models V and III at the FC and the models III and I at the WP (table 4).

\section{Correlations between estimated $\left(\theta_{\text {est }}\right)$ and measured soil water content $\left(\theta_{m}\right)$}

In order to test the applicability of the six PTFs to different soils of Apulia Region, the determination coefficients between soil moisture values estimated and measured in laboratory have been calculated, with regression lines trough zero also when the intercept values have been statistically different from zero (figure 3 and 4).

Determination coefficients between soil water content estimated and measured both at the FC and the WP are higher than 90, except for model III at WP, for which $\mathrm{R}^{2}$ is equal to 0.88 (table 2-3 and figure 3-4).

At FC the straight line slopes very near to $1(0.955$, 0.914 and 1.06) have been observed with the application of the models II, VI and I (table 2) giving the best performance, while at WP the straight line slopes close to 1 (1.008 and 1.02) have been observed applying the models II and VI (table 3).

According to the values of the determination coefficients and straight line slopes, the models that fit best the Apulian soil characteristics are: the I - II and $\mathrm{VI}$ at the FC, the II and VI at the WP.

\section{Discussion and conclusions}

The values of soil moisture estimated with the six PTFs tested for Apulian soils result closer to those determined in the laboratory at the Wilting Point (WP) than those at Field Capacity (FC), except for the model I that shows opposite behaviour.

Considering the statistical MD index, the best performances are recorded applying the model II at the FC, the models II and VI at the WP. The MD index values indicate that, for a number of soils, determining in laboratory the standard chemical and physical characteristics and applying the pedo-transfer models, it is very likely to have differences between estimated and measured soil water contents such that on average, they provide a low MD value; that is, the soil moistures estimated with the PTFs, on average, are very close to the ones determined in laboratory.

From a mathematically point of view, a low MD index value can derive:

- from low values of the differences between estimated and measured soil water contents;

- from more or less elevated values of the soil moisture differences but with opposite sign that, on average, they cancel out each other. 


\begin{tabular}{|c|c|c|c|c|c|c|c|c|c|c|c|c|c|c|}
\hline \multirow{3}{*}{ PTF } & \multirow{3}{*}{$\begin{array}{c}\begin{array}{c}\text { Straight } \\
\text { line slope } \\
\text { t standard } \\
\text { errars }\end{array} \\
\text { (b } \pm \text { es }\}\end{array}$} & \multirow{3}{*}{$\mathbf{R}^{\mathrm{t}}$} & Significance & & & \multicolumn{4}{|c|}{ Tendency clayey soils } & \multicolumn{4}{|c|}{ Tendency sandy sols } & \multirow{2}{*}{$\begin{array}{l}\text { Weighted } \\
\text { standard error } \\
\text { (WSEE) }\end{array}$} \\
\hline & & & $\operatorname{Pr}>|t|$ & SEE & AseE & $\begin{array}{c}\text { Straight } \\
\text { Ine slope } \\
\text { t standard } \\
\text { errors }\end{array}$ & \multirow[t]{2}{*}{$\mathrm{R}^{2}$} & SEE & ASEE & $\begin{array}{l}\text { Straight } \\
\text { Ine slope } \\
\pm \text { stendard } \\
\text { errers }\end{array}$ & \multirow[t]{2}{*}{$\mathbf{R}^{2}$} & SEE & ASEE & \\
\hline & & & (b) & \multicolumn{2}{|c|}{$m^{1} \cdot m^{-3}$} & $(b \pm e s)$ & & \multicolumn{2}{|c|}{$m^{2} \cdot m^{-1}$} & $(\mathrm{~b} \pm \mathrm{es})$ & & \multicolumn{3}{|c|}{$m^{2} \cdot m^{-3}$} \\
\hline $\begin{array}{c}\text { Model IV } \\
\text { (Rawls \& } \\
\text { Brakensick) }\end{array}$ & $\begin{array}{c}0,858= \\
0,012\end{array}$ & 0,94 & $<0,0001$ & 0,047 & 0.042 & $\begin{array}{c}1,07 \pm \\
0,019\end{array}$ & 0,98 & 0,042 & 0,038 & $\begin{array}{c}1.70 \pm \\
0,19\end{array}$ & 0.84 & 0,036 & 0.019 & 0.044 \\
\hline $\begin{array}{l}\text { Model II } \\
\text { (Raws) }\end{array}$ & $\begin{array}{c}1,008 \pm \\
0,01\end{array}$ & 0,94 & $<0,0001$ & 0,048 & 0,048 & $\begin{array}{c}1.17 \pm \\
0,023\end{array}$ & 0,98 & 0,082 & 0,043 & $\begin{array}{l}1.68 \pm \\
0,11\end{array}$ & 0,86 & 0,038 & 0.018 & 0.048 \\
\hline $\begin{array}{l}\text { Model V } \\
\text { (Saxten) }\end{array}$ & $\begin{array}{c}0.89= \\
0.01\end{array}$ & 0,92 & $<0,0001$ & 0,066 & 0.051 & $\begin{array}{l}1.14 \pm \\
0,023\end{array}$ & 0,98 & 0,080 & 0,046 & $\begin{array}{c}1.70 \pm \\
0.11\end{array}$ & 0,86 & 0,036 & 0.018 & 0.053 \\
\hline $\begin{array}{l}\text { Mosel V } \\
\text { (Vereecken) }\end{array}$ & $\begin{array}{l}1,02 * \\
0,015\end{array}$ & 0,80 & $<0,0001$ & 0,053 & 0.053 & $\begin{array}{l}1.25 t \\
0,022\end{array}$ & 0,98 & $0,07 \theta$ & 0,045 & $\begin{array}{c}1.41 \pm \\
0,08\end{array}$ & 0,97 & 0,020 & 0.014 & 0.054 \\
\hline $\begin{array}{l}\text { Model III } \\
\text { (De Jong) }\end{array}$ & $\begin{array}{l}0.72 \pm \\
0,014\end{array}$ & 0,86 & $<0,0001$ & 0,072 & 0,049 & $\begin{array}{l}0.90 \pm \\
0.018\end{array}$ & 0,88 & 0,043 & 0,035 & $\begin{array}{c}1.76 \pm \\
0,13\end{array}$ & 0,86 & 0,038 & 0.019 & 0.060 \\
\hline $\begin{array}{l}\text { Model I } \\
\text { (Gupta \& } \\
\text { Larson) }\end{array}$ & $\begin{array}{c}1.288= \\
0,014\end{array}$ & 0,96 & $<0,0001$ & 0,071 & 0.050 & $\begin{array}{l}1.42 \pm \\
0.028\end{array}$ & $0,9 \mathrm{e}$ & 0,122 & 0,051 & $\begin{array}{l}2.3 \pm \\
0.155\end{array}$ & 0,56 & 0,053 & 0,025 & 0,069 \\
\hline
\end{tabular}

TABLE 3 - Regression parameters between measured and estimated with six PTFs soil moisture values at Wilting Point (\% volume) setting intercepts to zero; indexes SEE, ASEE and WSEE values.

\begin{tabular}{|c|c|c|c|c|c|c|c|c|c|c|c|}
\hline \multicolumn{6}{|c|}{$\begin{array}{l}\text { Mean deviation } \\
\qquad M D \pm s e\} \\
\left(m^{2} \cdot m^{-3}\right)\end{array}$} & \multicolumn{6}{|c|}{$\begin{array}{l}\text { Root mean squared deviation } \\
\qquad \begin{array}{c}\text { RMSO } \pm \text { se }\rangle \\
\left(\mathrm{m}^{3} \cdot \mathrm{m}^{-3}\right)\end{array}\end{array}$} \\
\hline PTF & $\mathrm{FC}$ & & PTF & WP & & PTF & $F C$ & & PTF & WP & \\
\hline $\begin{array}{l}\text { Model I } \\
\text { (Guptas } \\
\text { Larson) }\end{array}$ & $\begin{array}{l}0,030= \\
0,0031\end{array}$ & A & $\begin{array}{l}\text { Moded I } \\
\text { (Gupta s } \\
\text { Larson) }\end{array}$ & $\begin{array}{l}0,053= \\
0,0025\end{array}$ & A & $\begin{array}{l}\text { Model II } \\
\text { (Rawls) }\end{array}$ & $\begin{array}{l}0,059= \\
0,0019\end{array}$ & D & $\begin{array}{l}\text { Model N } \\
\text { (Rasis \& } \\
\text { Brakeraiek) }\end{array}$ & $\begin{array}{l}0,046 \pm \\
0,0016\end{array}$ & c \\
\hline $\begin{array}{l}\text { Model II } \\
\text { (Rawls) }\end{array}$ & $\begin{array}{c}-0,007 \pm \\
0,0031\end{array}$ & $B$ & $\begin{array}{l}\text { Model II } \\
\text { (Rasws) }\end{array}$ & $\begin{array}{l}0,006 \pm \\
0,0025\end{array}$ & $B$ & $\begin{array}{l}\text { Model } \\
\text { MiVeroecke } \\
\text { n) }\end{array}$ & $\begin{array}{l}0,051 \pm \\
0,0020\end{array}$ & $\mathrm{D}$ & $\begin{array}{l}\text { Model II } \\
\text { (Rranis) }\end{array}$ & $\begin{array}{l}0,047 \pm \\
0,0015\end{array}$ & $\mathrm{BC}$ \\
\hline $\begin{array}{l}\text { Modal v1 } \\
\text { (Voreockan) }\end{array}$ & $\begin{array}{c}-0,019 \neq \\
0,0030\end{array}$ & c & $\begin{array}{c}\text { Model VI } \\
\text { (Vertooken) }\end{array}$ & $\begin{array}{l}0,005= \\
0,0028\end{array}$ & $B$ & $\begin{array}{l}\text { Model I } \\
\text { (Gupts \& } \\
\text { Larson) }\end{array}$ & $\begin{array}{l}0,056= \\
0,0020\end{array}$ & $\begin{array}{l}\text { C } \\
\text { D }\end{array}$ & $\begin{array}{l}\text { Model VI } \\
\text { Wernecken) }\end{array}$ & $\begin{array}{l}0,053 \pm \\
0,0017\end{array}$ & B \\
\hline $\begin{array}{l}\text { Model IV } \\
\text { (Rawls s } \\
\text { Brakensiek) }\end{array}$ & $\begin{array}{c}-0,045 \pm \\
0,0029\end{array}$ & $D$ & $\begin{array}{l}\text { Model IV } \\
\text { (Rrawls s } \\
\text { Brakensiak) }\end{array}$ & $\begin{array}{c}-0,016 \pm \\
0,0023\end{array}$ & c & $\begin{array}{l}\text { Medel IV } \\
\text { (Rawls \& } \\
\text { Brakensiak) }\end{array}$ & $\begin{array}{l}0,070 \pm \\
0,0022\end{array}$ & c & $\begin{array}{l}\text { Model V } \\
\text { (Saxten) }\end{array}$ & $\begin{array}{l}0,055 \pm \\
0,0018\end{array}$ & B \\
\hline $\begin{array}{l}\text { Model V } \\
\text { (Saxton) }\end{array}$ & $\begin{array}{c}-0,084 \pm \\
0,0042\end{array}$ & $E$ & $\begin{array}{l}\text { Model V } \\
\text { (Saxton) }\end{array}$ & $\begin{array}{c}-0,018 \pm \\
0,0027\end{array}$ & c & $\begin{array}{l}\text { Model V } \\
\text { (Saxton) }\end{array}$ & $\begin{array}{l}0,102 \pm \\
0,0031\end{array}$ & $\mathrm{~B}$ & $\begin{array}{l}\text { Modal I } \\
\text { (Gupta \& } \\
\text { Larson) }\end{array}$ & $\begin{array}{l}0,071 \pm \\
0,0021\end{array}$ & A \\
\hline $\begin{array}{l}\text { Model III } \\
\text { (De Jang) }\end{array}$ & $\begin{array}{c}-0.081 \pm \\
0.0048\end{array}$ & $F$ & $\begin{array}{l}\text { Model III } \\
\text { (De Jong) }\end{array}$ & $\begin{array}{c}-0,046 \pm \\
0,0029\end{array}$ & $D$ & $\begin{array}{l}\text { Model III } \\
\text { (De Jang) }\end{array}$ & $\begin{array}{l}0,121= \\
0,0037\end{array}$ & A & $\begin{array}{l}\text { Model III } \\
\text { (De Jorg) }\end{array}$ & $\begin{array}{l}0,072 \pm \\
0,0023\end{array}$ & A \\
\hline
\end{tabular}

TABLE 4 - Mean Deviation and Root Mean Squared Deviation of differences between estimated and measured soil moisture values for total data set. 

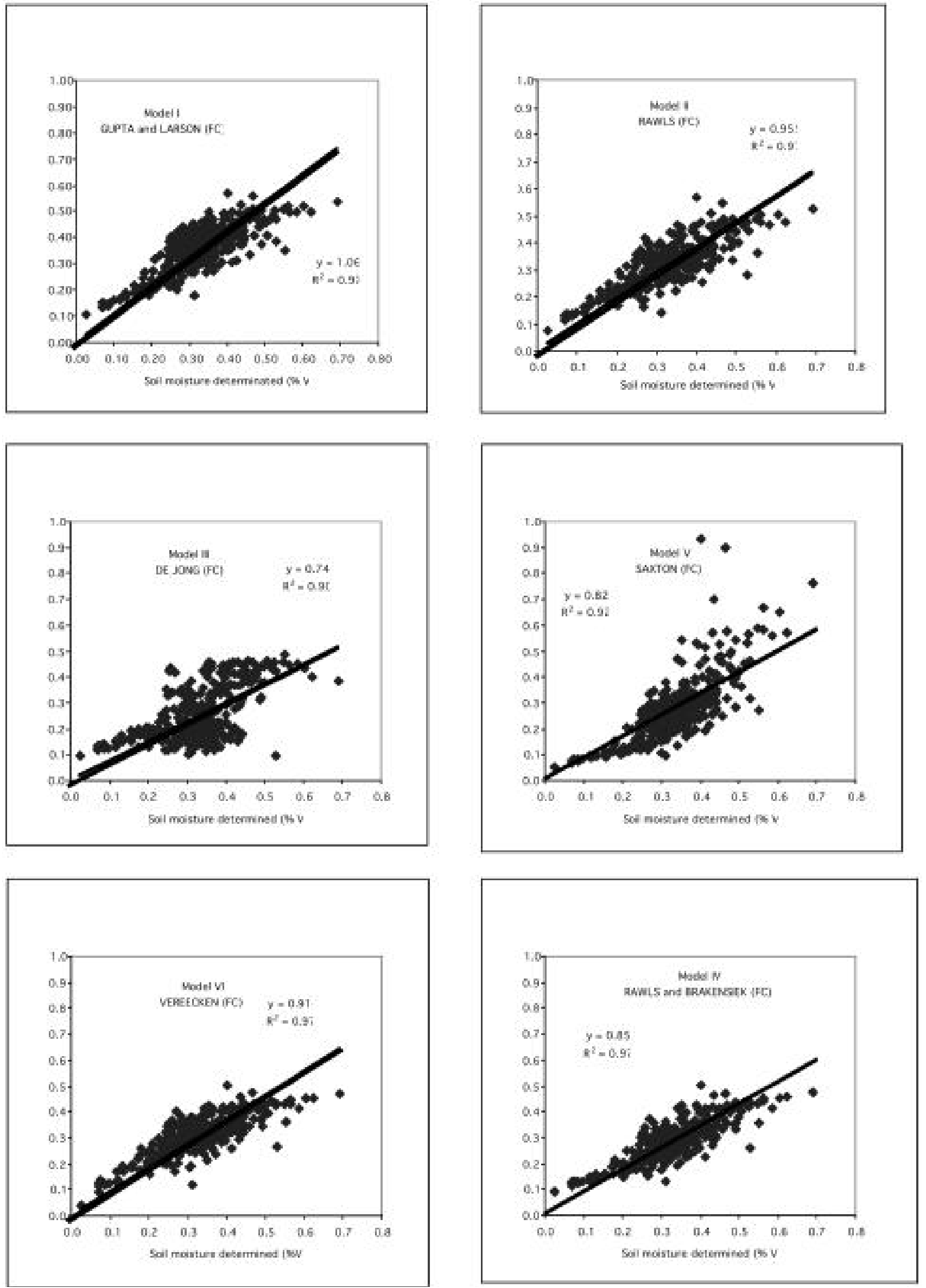

Fig. 3 - Regression lines through zero between estimated and measured soil moisture values at the Field Capacity. 
These results point out the importance of WSEE and RMSD indexes. In the mathematic formulation of these two indexes, the squaring of the values of the differences between estimated and measured soil water contents eliminates the effect of the opposite sign, and therefore it shows a real view of the values entity error; a hypothetical MD value equal to that of the RMSD value indicates, practically, that the soil moisture differences have all the same mathematic sign. In other words, RMSD index in the series of available $\Delta \theta$, quantifies the effect of the mutual annulment of elevated soil moisture differences but with opposite mathematic sign.

The results of this validation research on the adaptability of the six PTFs in Apulian soils show that, at the Field Capacity, the lowest values of WSEE, RMSD and MD indexes have been obtained with the model II; in this case the lowest MD value is influenced more from low values of the differences between estimated and measured soil water contents than from the annulment of opposite sign differences.

At the Wilting Point, instead, the model IV provides the lowest WSEE and RMSD values; respect to this last PTF, the ones of the model II and VI, even if gave the lowest MD values (0.6 and $0.5 \%$ vs. $1.6 \%$ moisture in volume), surely they come, in the series of available $\Delta \theta$, from the greater number of elevated soil water moisture differences that cancel out each other. Therefore, at the WP the best performance has been obtained by applying the model IV.

From these considerations, it is possibile to make the following conclusions for each model.

\section{Model I (Gupta \& Larson, 1979)}

a) Among the PTFs studied, Gupta \& Larson is the PTF that asks for the greatest number of input parameters for its application (5 parameters);

b) for Apulian soils, it is the unique PTF that on average overestimates the soil water contents both at the FC $\left(\mathrm{MD}=0.03 \mathrm{~m}^{3} \cdot \mathrm{m}^{-3}\right)$ and $\mathrm{WP}(\mathrm{MD}=0.053$ $\mathrm{m}^{3} \cdot \mathrm{m}^{-3}$ ), according to the validation research of Tietje \& Tapkenhinrichs (1993) that used two data sets of soil samples collected in Germany [Othmer 1989; Bachmann 1992] and of Kern (1995) that used a data set of soil samples collected in USA territory and reported in the USDA-SCS National Soil Survey Laboratory Pedon Database; Williams et al., (1992) instead, report that, at the corresponding $-1500 \mathrm{KPa}$ matric potential, Gupta \& Larson model underestimates the soil water content of $0.029 \mathrm{~m}^{3} \cdot \mathrm{m}^{-3}$;

\section{Model II (Rawls et al.,1982)}

a) This PTF is very easy to apply in that it asks for only the soil particle size distribution and the organic matter content;

b) it produces MD and RMSD values $(<1 \%$ and $\leq 6$ $\%$ in volume, respectively) similar to the literature values [Tietje 1993; Kern 1995]; both at the FC and the WP, the MD and RMSD values result the lowest of the all tested PTFs;

\section{Model III (De Jong et al., 1983)}

Suggested, in origin, for Canadian soils, this PTF, in Apulian soils, produces high statistical errors for the evaluation of soil water content at all matric potentials; indeed, the WSEE, MD and RMSD values are the highest and the correlation coefficients between estimated and measured soil water contents are the lowest;

\section{Model IV (Rawls \& Brakensiek, 1985)}

In agreement with Tietje \& Tapkenhinrichs (1993), the Rawls \& Brakensiek PTF underestimates the soil water content, on average, of the 4.5 and $1.6 \%$ at the FC and the WP respectively; however, the statistic parameter values are similar, at the WP even lower, to the ones reported for soils of Emilia Romagna and Lombardia (MD 0.02-0.07; RMSD 0.08-0.09 $\mathrm{m}^{3} \cdot \mathrm{m}^{-3}$ ) [Ungaro 2001] and they are considered satisfactory by the same authors.

\section{Model V (Saxton et al., 1986)}

a- It is the PTF that utilizes the least number of input parameters: the clay and sand contents are only necessary;

b- among the six validated PTFs, it provides, for the Apulian soil set, one of the highest MD values at the FC ( $>6 \%$ in volume) and one of the lowest MD values at the WP ( $<2 \%$ in volume); however, for Apulian soils, the MD and RMSD values are clearly higher than the ones reported in literature, validating Saxton model in the centre Europe soils [Tietje 1993], in Italy (Emilia Romagna and Lombardia soils) [Ungaro 2001] and in USA [Kern 1995];

\section{Model VI (Vereecken et al., 1989)}

a- This PTF presents the disadvantage to require soil bulk density, a parameter often not available and difficult to evaluate;

b- it is the PTF that, except the one of Rawls et al. (1982), gives the lowest soil water MD values $(<2$ $\%$ in volume at the FC; $0.5 \%$ at the WP); these values are similar to those reported from Tietje \& Tapkenhinrichs (1993) fo the centre Europe (Germany) soils, but practically contrary in sign and values, for the estreme points of water retention curve, to the values recorded by Kern (1995) in USA soils $\left(\mathrm{MD}_{\mathrm{CIC}}=-0.009 ; \mathrm{MD}_{\mathrm{PA}}=0.020 \mathrm{~m}^{3} \cdot \mathrm{m}^{-3}\right)$; this model provides $\mathrm{MD}$ and RMSD values lower than the ones obtained from Ungaro \& Calzolari (2001) in Emilia Romagna and Lombardia soils; moreover MD values are also lower of those obtained in Belgium from Cornelis et al., (2001) that consider this PTF the best one.

In conclusion, among the six PTFs tested in Apulian soils, the best performance have been obtained with the following models: Rawls and Vereecken at the Field Capacity; Rawls \& Brakensiek and Rawls at the Wilting Point. 

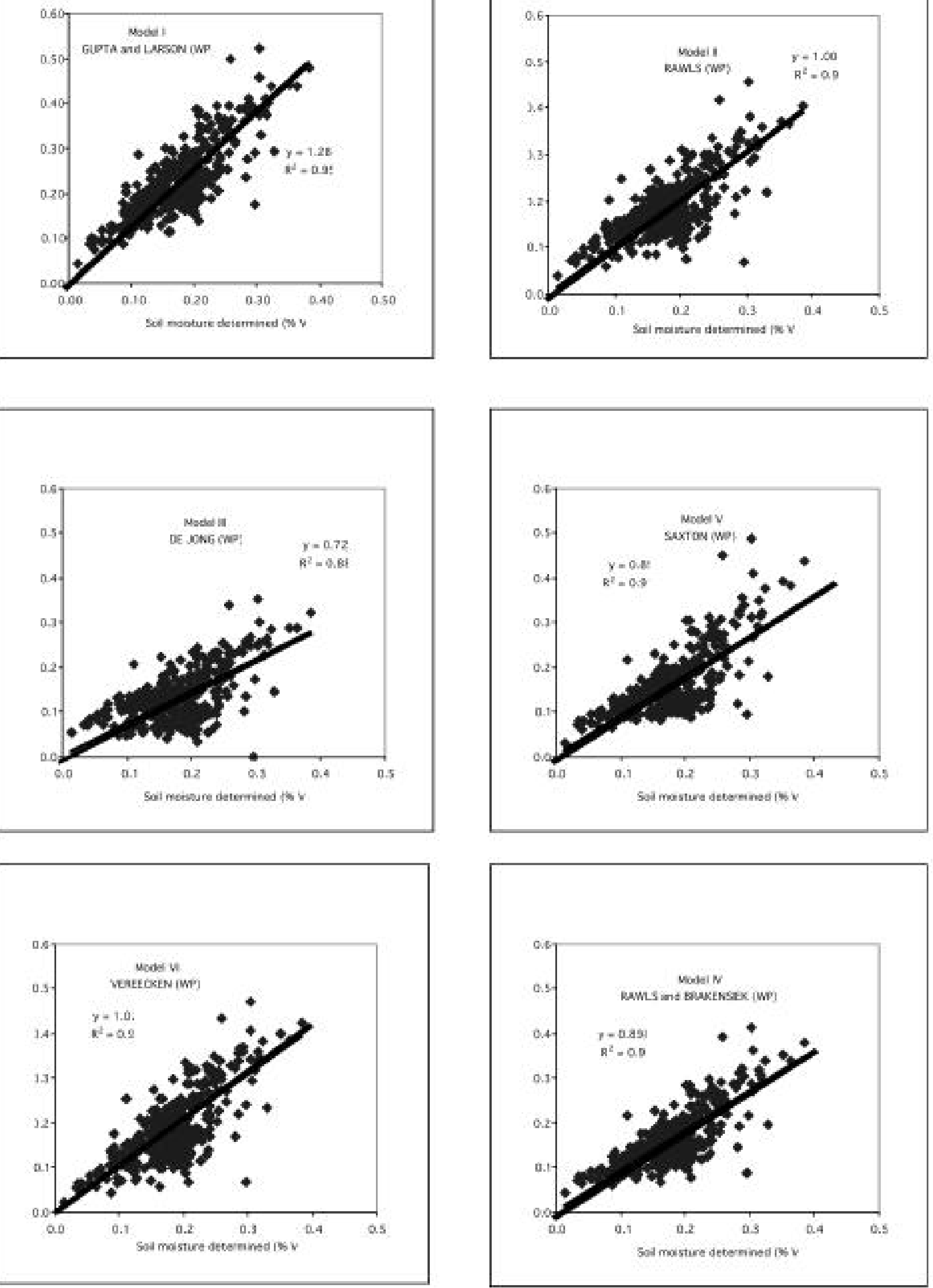

Fig. 4 - Regression lines through zero between estimated and measured soil moisture values at the Wilting Point. 


\section{References}

ADAMS W.A., The effect of organic matter on the bulk and true densities of some uncultivated podzoilc soils. Journal of Soil Science, 1973, 24, 10-17.

Ahuja L.R., NANey J.W., Williams R.D., Estimating soil water characteristics from simpler properties or limited data. Soil Science Society of America Journal, 1985, 49, 1100-1105.

Aina P.O., Periaswamy S.P., Estimating available waterholding capacity of western nigerian soils from soil texture and bulk density, using core and sieved samples. Soil Science, 1985, 140, 55-58.

AlEXANDER E.B., Bulk densities of California soils in relation to other soil properties. Soil Science Society of America Journal, 1980, 44, 689-692.

Allen R.G., Jensen M.E., Wright J.L., Burman R.D., Operational estimates of reference evapotraspiration. Agronomy Journal, 1989, 81, 650-662.

ARYA L.M., PARIS J.F., A physicoempirical model to predict the soil moisture characteristic from particle-size distribution and bulk density data. Soil Science Society of America Journal, 1981, 45, 1023-1030.

BACHMANN J., HARTGE K.H., Estimating soil water characteristics obtained by basic soil data - A comparison of indirect methods. (In German.) Zeitschrift fur Pflanzenernähr. Bodenkd., 1992, 155, 109-114. In Tietje \& Tapkenhinrichs 1993.

BATJES N.H., Development of a world data set of soil water retention properties using pedotransfer rules. Geoderma, 1996, 71, 31-52.

Bell M.A., van Keulen H., Soil Pedotransfer functions for four Mexican soils. Soil Science Society of America Journal, 1995, 59, 865-871.

Bouma J., Using soil survey data for quantitative land evaluation. Advances in Soil Science, 1989, 9, 177-213.

Brooks R.H., Corey A.T., Hydraulic properties of porous media. Hydrology Paper no. 3, 1964, Colorado State University, Fort Collins. In Saxton et al. 1986.

BRUTSAERT W., Probability laws for pore-size distributions. Soil Science, 1966, 101, 85-92.

CAMPBELl G.S., A simple method for determining unsaturated conductivity from moisture retention data. Soil Science, 1974, 117, 311-314.

Cosby B.J., Hornberger G.M., Clapp R.B., GinN T.R., A statistical exploration of soil moisture characteristics to the physical properties of soils. Water Resources Research, 1984, 20, 682-690.

Cornelis W.M., Ronsyn J., Meirvenne M. Van, HartMANN R., Evaluation of Pedotransfer functions for predicting the soil moisture retention curve. Soil Science Society of America Journal, 2001, 65, 638-648.

CRESSwell H.P., PAYdAR Z., Functional evaluation of methods for predicting the soil water characteristic. Journal of Hydrology, 2000, 227, 160-172.

CuRTis R.O., Post B.W., Estimating bulk density from organic-matter content in some Vermont forest soils. Soil Science Society of America Proceedings, 1964, 28, 285286

DaAmen C.C., Xiao Z., Robinson J.A., Estimation of water-retention function using scaling theory and soil physical properties. Soil Science Society of America Journal, $1990,54,8-13$
DAVIS J.C., Statistical and data analysis in geology. 1973, Wiley, New York. In Rawls 1982.

De Jong R., Campbell C.A., Nicolaichuk W., Water retention equations and their relationship to soil organic matter and particle size distribution for disturbed samples. Canadian Journal of Soil Science, 1983, 63, 291-302.

D'Hollander E.M., Estimation of the pore-size distribution from the moisture characteristic. Water Resources Research, 1979, 15 (1), 107-112.

FARREL D.A., LARSON W.E., Modelling of the pore structure of porous media. Water Resources Research, 1972, 8, 699-706.

GHOSH R.K., Estimation of soil-moisture characteristics from mechanical properties of soils. Soil Science, 1980, 130, 60-63.

GuPTA S.C., LARSON W.E., A model for predicting packing density of soils using particle-size distribution. Soil Science Society of America Journal, 1979 a, 43, 758-764.

GuPTA S.C., LARSON W.E., Estimating soil water retention characteristics from particle size distribution, organic matter content, and bulk density. Water Resources Research, 1979 b, 15, 1633-1635.

JAMISON V.C., КROTH E.M., Available moisture storage capacity in relation to textural composition and organic matter content of several Missouri soils. Soil Science Society of America Proceedings, 1958, 22, 189-192.

Haverkamp R., Parlange J.Y., Predicting the water-retention curve from particle-size distribution: 1 . sandy soils without organic matter. Soil Science, 1986, 142, 325-339.

HEINONEN R., Towards "normal" soil bulk density. Soil Science Society of America Journal, 1977, 41, 1214-1215.

HoDnetT M.G., Tomasella J., Marked differences between van Genuchten soil water-retention parameters for temperate and tropical soils: a new water-retention pedotransfer functions developed for tropical soils. Geoderma, 2002, 108, 155-180.

KERN J.S., Evaluation of soil water retention models based on basic soil physical properties. Soil Science Society of America Journal, 1995, 59, 1134-1141.

Leij F.J., Romano N., Palladino M., SchaAp M.G., CoppoLA A., Topographical attributes to predict soil hydraulic properties along a hillslope transect. Water Resources Research, 2004, 40.

LEONAVIČIIUTÉ N., Predicting soil bulk and particle densities by Pedotransfer Functions from existing soil data in Lithuania. Geografijos metraštis, 200033 t.

Lin H.S., McInNes K.J., Wilding L.P., Hallmark C.T., Effect of soil morphology on hydraulic properties: II. Hydraulic pedotransfer functions. Soil Science Society of America Journal, 1999, 63, 955-961.

LuND Z.F., Available water-holding capacity of alluvial soils in Louisiana. Soil Science Society of America Proceedings, 1959, 23, 1-3.

MACLEAN A.H., YAger T.U., Available water capacities of Zambian soils in relation to pressure plate measurements and particle size analysis. Soil Science, 1972, 113, 23 29.

MAYr T., JaRvis N.J., Pedotransfer functions to estimate soil water retention parameters for a modified BrooksCorey type model. Geoderma, 1999, 91, 1-9.

McKeague J.A., Estimating air porosity and available water capacity from soil morphology. Soil Science Society of America Journal, 1987, 51, 148-152. 
Meng T.P., TaYlor H.M., Fryrear D.W., Gomez J.F., Models to predict water retention in semiarid sandy soils. Soil Science Society of America Journal, 1987, 51, 1563-1565.

Nemes A., SchaAp M.G., Lejt F.J., Wösten J.H.M., Description of the unsaturated soil hydraulic database UNSODA version 2.0. Journal of Hydrology, 2001, 251, 151-162.

Nemes A., SchaAp M.G., Wösten J.H.M., Functional evaluation of Pedotransfer functions derived from different scales of data collection. Soil Science Society of America Journal, 2003, 67, 1093-1102.

NiELSEN D.R., SHAw R.H., Estimation of the 15-atmosphere moisture percentage from hydrometer data. Soil Science, 1958, 86, 103-106.

Odeh I.O.A., McBratney A.B., Chittleborough D.J., Spatial prediction of soil properties from landform attributes derived from a digital elevation model. Geoderma, 1994, 63, 197-214.

OTHMER H., Bork H.R., Characterization of the soils at the investigation sites. Landschaftsgenese Landschaftsökologie, 1989, 16, 73-86. In Tietje \& Tapkenhinrichs 1993.

PACHEPSKY Y.A., RAWLS W.J., Soil structure and pedotransfer functions. European Journal of Soil Science, 2003, 54, 443-451.

Petersen G.W., Cunningham R.L., Matelski. Moisture characteristics of Pennsylvania soils: I. Moisture retention as related to texture. Soil Science Society of America Proceedings, 1968 a, 32, 271-275.

Petersen G.W., Cunningham R.L., Matelski. Moisture characteristics of Pennsylvania soils: II. Soil factors affecting moisture retention within a textural class-silt loam. Soil Science Society of America Proceedings, 1968 b, 32, 866-870.

Prebble R.E., STIRK G.B., Effect of free iron oxide on range of available water in soils. Soil Science, 1959, 88, 213-217.

Puckett W.E., Dane J.H., Hajek B.F., Physical and mineralogical data to determine soil hydraulic properties. Soil Science Society of America Journal, 1985, 49, 831-836.

RAJKAI K., KABOS S., vAN GENUChTEN M.T., Estimating the water retention curve from soil properties: comparison of linear, nonlinear and concomitant variable methods. Soil Tillage Research, 2004, 79, 145-152.

RAWLS W.J., Estimating soil bulk density from particle size analysis and organic matter content. Soil Science, 1982. 135 No.2, 123-125.

Rawls W.J., Brakensiek D.L., Prediction of soil water properties for hydrological modelling. 1985 In Ungano \& Calzolari 2001.

RAWLS W.J., BRAKENSIEK D.L., Estimation of soil water retention and hydraulic properties. 1989 In H.J. MorelSeytoux (ed.). Unsaturated Flow in Hydrologic Modeling, Theory and Practice, 275-300.

RAWLS W.J., BRAKENSIEK D.L., SAXTON K.E., Estimation of soil water properties. Trans. ASAE, 1982, 25, 13161320. In Saxton et al. 1986.

RaWls W.J., Gish T.J., BRAKensieK D.L., Estimating soil water retention from soil physical properties and characteristics. Advances in Soil Science, 1991, 16, 213-234.

RAWLS W.J., PACHEPSKY Y.A., Soil consistence and structure as predictors of water retention. Soil Science Society of America Journal, 2002 a, 66, 1115-1126.
RAWLS W.J., PAChEPSKY Y.A., Using field topographic descriptors to estimate soil water retention. Soil Science, 2002 b, 167, 235-423.

RaWls W.J., Pachepsky Y.A., Ritchie J.C., Sobecki T.M., BLOODWORTH H., Effect of soil organic carbon on soil water retention. Geoderma, 2003, 116, 61-76.

RaWls W.J., PAchePsky Y.A., Shen M.H., Testing soil water retention estimation with the MUUF pedotransfer model using data from the southern United States. Journal of Hydrology, 2001, 251, 177-185.

RichaRDS L.A., Methods of measuring soil moisture tension. Soil Science, 1949, 68, 95-112.

Richards L.A., WeaVer L.R., Pressure-membrane apparatus-construction and use. Agricultural Engineering, 1947, 28, 451-454.

Romano N., Palladino M., Prediction of soil water retention using soil physical data and terrain attributes. Journal of Hydrology, 2002, 265, 56-75.

SAINI G.R., Organic matter as a measure of bulk density of soil. Nature, 1966, 210, 1295-1296. In Alexander 1980.

SAlter P.J., BerRy G., Williams J.B., The influence of texture on the moisture characteristics of soils. III. Quantitative relationships between particle size composition and available-water capacity. Journal of Soil Science, 1966, 17, 93-98.

SAlter P.J., Williams J.B., The influence of texture on the moisture characteristics of soils. I. A critical comparison of techniques for determining the available-water capacity and moisture characteristic curve of a soil. Journal of Soil Science, 1965 a, 16, 1-15.

SALTER P.J., Williams J.B., The influence of texture on the moisture characteristics of soils. II. Available-water capacity and moisture release characteristics. Journal of Soil Science, 1965 b, 16, 310-317.

Salter P.J., Williams J.B., The influence of texture on the moisture characteristics of soil. V. Relationships between particle-size composition and moisture contents at the upper and lower limits of available-water. Journal of Soil Science, 1969, 20, 126-131.

Saxton K.E., Rawls W.J., Romberger J.S., Papendick R.I., Estimating generalized soil-water characteristics from texture. Soil Science Society of America Journal, 1986, 50, 1031-1036.

Scheinost A.C., SinOwsKi W.E., Auerswald K., Regionalization of soil water retention curves in a highly variable soilscape. I. Developing a new pedotransfer function. Geoderma, 1997, 78, 129-143.

Simota C., Mayr T., Pedotransfer function. 1996. In Ungaro \& Calzolari 2001.

STANHILl G., The effect of differences in soil-moisture status on plant growth: a review and analysis of soil moisture regime experiments. Soil Science, 1957, 84, 205-214.

STIRK G.B., Physical properties of soils of the Lower Burdekin Valley, North Queensland., 1957, C.S.I.R.O., Australia, Division of Soils, Div. Rpt., 1/57.

TIETJE O., TAPKEnhinRIChS M., Evaluation of Pedo-Transfer Function. Soil Science Society of America Journal, 1993, 57, 1088-1095.

Tomasella J., HodnetT M.G., Estimating soil water retention characteristics from limited data in Brazilian Amazonia. Soil Science, 1998, 163, 190-199.

Tomasella J., Hodnett M.G., Rossato L., Pedo-Transfer Functions for the estimation of soil water retention in 
Brazilian soils. Soil Science Society of America Journal, 2000, 64, 327-338.

Torrent J., Schwertmann U., Fechter H., Alferez F., Quantitative relationships between soil color and hematite content. Soil Science, 1983 136, 354-358.

TYleR W., Wheatcraft S.W., Application of fractal mathematics to soil water retention estimation. Soil Science Society of America Journal, 1989, 53, 987-996.

Ungaro F., CAlzolari C., Using existing soil databases for estimating retention properties for soils of the Pianura Padano-Veneta region of North Italy. Geoderma, 2001, 99, 99-121.

VAN GENUChTEN M.T., A closed-form equation for predicting the hydraulic conductivity of unsatured soils. Soil Science Society of America Journal, 1980, 44, 892-898.

Vereecken H., Maes J., Feyen J., Darius P., Estimating the soil moinsture retention characteristic from texture, bulk density, and carbon content. Soil Science, 1989, 148, 389-403.

Williams J. R., Prebble E., Williams W. T., Hignett C.T., The influence of texture, structure and clay mineralogy on the soil moisture characteristic. Australian Journal of Soil Research, 1983, 21, 15-31.

Williams R.D., Ahuja L.R., Naney J.W., Comparisons of methods to estimate soil water characteristics from soil particle size distribution, bulk density, and limited data. Soil Science, 1992, 153, 172-184.

Wösten J.H.M., Lilly A., Nemes A., Le Bas C., Development and use of a database of hydraulic properties of European soils. Geoderma, 1999, 90, 169-185.

WÖsten J.H.M., PAChePSKY Ya.A., RAWls W.J., Pedotransfer functions: bridging the gap between available basic soil data and missing soil hydraulic characteristics. Journal of Hydrology, 2001, 251, 123-150.

WÖsTEN J.H.M., vAN GENUCHTEN M.T., Using texture and other soil properties to predict the unsaturated soil hydraulic functions. Soil Science Society of America Journal, 1988, 52, 1762-1770.

\section{SUMMARY}

The knowledge of soil water retention vs. soil water matric potential is used to study irrigation and drainage schedules, soil water storage capacity (plant available water), solute movement, plant growth and water stress.

The hydraulic soil properties measuring is expensive, laborious and takes too long time, so, frequently, matemathic models, called pedo-transfer functions (PTFs) are utilized to estimate hydraulic soil properties through soil chimical and phisical characteristics.

Six pedo-transfer functions have been evaluated (Gupta \& Larson, 1979; Rawls et al., 1982; De Jong et al., 1983; Rawls \& Brakensiek, 1985; Saxton et al., 1986; Vereecken et al., 1989) by comparing estimated with measured soil moisture values at soil water matric potential of -33 and $-1500 \mathrm{kPa}$ of 361 soil samples collected from 185 pedons of Apulia Region (South Italy), having various combinations of particle-size distribution, soil organic matter content and bulk density.

Accuracy of the soil moisture predictions have been evaluated by statistic indexes such as Weighted stantard error (WSEE), Mean Deviation (MD), Root Mean Squared Deviation (RMSD) and the determination coefficient $\left(\mathrm{R}^{2}\right)$ between estimated and measured water retention values.

The Rawls PTF model demostrated to have the lowest values of WSEE, MD and RMSD indexes (0.044, -0.007 and $0.059 \mathrm{~m}^{3} \mathrm{H}_{2} \mathrm{O} \mathrm{m}^{-3}$ soil, respectively) at $-33 \mathrm{Kpa}$ soil water matric potential (Field Capacity), while for estimating soil moisture at the Wilting Point $(-1500 \mathrm{kPa})$ Rawls \& Brakensiek model is adequate (WSEE, MD and RMSD of 0.034, -0.016 and $0.046 \mathrm{~m}^{3} \mathrm{H}_{2} \mathrm{O} \mathrm{m} \mathrm{m}^{-3}$ soil).

De Jong, Saxton and Rawls \& Brakensiek models, at $-33 \mathrm{kPa}$ soil water matric potential and Gupta \& Larson and De Jong models at $-1500 \mathrm{kPa}$ soil water matric potential, showed the highest statistic errors.

Keywords: Hydraulic soil properties, pedotransfer functions, soil water retention models. 


\section{CIOSTA-CIGR V Conference - Reggio Calabria, 17-19 June 2009}

The XXXIII CIOSTA-CIGR V Conference "TECHNOLOGY AND MANAGEMENT TO ENSURE SUSTAINABLE AGRICULTURE, AGRO-SYSTEMS, FORESTRY AND SAFETY" held at the University "Mediterranea" of Reggio Calabria, 17-19, June 2009 has been recently concluded. The event was organized by Professors Gennaro Giametta and Giuseppe Zimbalatti, as Ciosta President and Coordinator, respectively, in concert with Professor Pietro Piccarolo, CIGR V Section President, and with the support of other very prestigious scientific organisms which promote the research in this field: CIGR, EurAgeng e AIIA. Inside the Conference, a IUFRO workshop (Unit 3.06.00), about "Forestry utilization in Mediterranean Countries with particular respect to sloping areas" whose referee was Prof. Zimbalatti - was held. The guests who took part in the conference were more than three hundred with a total of four hundred reports which represent the future for the experts of the field.

The first meeting was in the evening of the $16^{\text {th }}$ of June, when all the guests gathered in order to be welcomed by the organizers and by the city, for an Ice breaking dinner offered by the Government of Reggio Calabria, in the city promenade which faces the Straits of Messina, described as "the finest mile in Italy" by the Italian poet Gabriele D'Annunzio. On Wednesday $17^{\text {th }}$ in the morning, at the Faculty of Agriculture there was the opening ceremony introduced by Professor Giametta, in the presence of all the institutional authorities of Calabria. In succession the opening scientific session, introduced by Professor Zimbalatti, started. The most important members of the promoting associations took part: Søren Pedersen (CIGR President), Antonino Failla (AIIA President, Italy).

During this phase two of the world most important experts, the Japanese Naoshi Kondo and Masami Shiba reported, respectively, on robotics in agriculture and the problems linked to the globalization of the wood row. On Wednesday, in the afternoon, and on Thursday, until the Conference closing ceremony, at the Faculty the refereers split up into oral and poster sessions, divided into 15 themes, in order to discuss the latest innovations in the field of Agro-Forestry mechanization and systems with the consequent aspects as concerns safety, environmental protection and work organization. These are the figures of the event: 942 authors from 60 Countries and 5 Continents have contributed to the Proceedings of the Conference volume (2368 pages); 393 papers (161 oral presentation - 232 poster presentation).

Many were the field experiences for the delegations coming from the four corners of the earth. See the "techincgastronomic appendix" of the first day with demonstration of the agricultural machines produced by "De Masi" factory, one of the calabrian "excellences", with dinner at the "Uliveto Principessa Resort" of Cittanova. Many were the occasions of cultural exchanges as well, with the visit to the National Museum of Magna Grecia of Reggio Calabria. The whole delegation was also received at "Palazzo Foti" by the President of the Provincial Council Giuseppe Giordano and by the councillor Antonio Scali, who congratulated on the big success of the Conference. There was also a tour through the wonderful landscapes of the "COSTA VIOLA" and the olive-grove scenery in the Grecian Area with visit and refreshment at Capogreco Olive-oil factory, other excellence in Calabria. Also the parallel tour through the National Park of Aspromonte, realized with the support of the National Forester Corps, was very appreciated by all the Conference Partecipants.

The next XXXIV Ciosta Conference "Efficient and safe production processes in sustainable agriculture and forestry" will be held in Vienna, 29 June - 1 July 2011. 